\title{
DETERMINAN PEMBERIAN ASI ESKSKLUSIF
}

\author{
Determinan Giving Esclusive ASI
}

Ani Nur Fauziah ${ }^{1}$, Sri Suparti ${ }^{2}$

STIKES Mamba'ul Ulum Surakarta

(aninurfauziah@stikesmus.ac.id)

\begin{abstract}
ABSTRAK
Latar Belakang : ASI merupakan makanan tunggal yang dapat memenuhi kebutuhan bayi hingga 6 bulan. ASI eksklusif 6 bulan pertama kehidupan bayi yang diimbangi dengan pemberian MP ASI yang optimal merupakan intervensi kesehatan masyarakat yang sangat efektif dan efisien dalam mendukung pertumbuhan balita.

Tujuan :penelitian ini bertujuan untuk mengetahui determinan pemberian ASI Eksklusif di RW 12 Kalurahan Mojosongo Surakarta meliputi : umur, pendidikan, pekerjaan serta pengetahuan ibu tentang ASI Eksklusif

Metode :Penelitian ini termasuk jenis penelitian analitik dengan pendekatan waktu cross sectional. Populasi dalam penelitian ini adalah seluruh ibu yang mempunyai bayi di RW 12 Kalurahan Mojosongo Kecamatan Jebres Surakarta. Pada penelitian ini menggunakan purposive sampling yaitu teknik penentuan sampel berdasarkan syarat tertentu yaitu ibu yang memiliki bayi di atas 6 bulan sejumlah 161 responden. Alat pengumpulan data pada penelitian ini yaitu kuesioner. untuk mengetahui tingkat signifikasi hubungan dapat dilakukan dengan membandingkan nilai chi kuadrat $\left(\mathrm{x}^{2}\right)$ hitung dengan nilai chi kuadrat $(\mathrm{x})$ tabel sesuai dengan tingkat signifikan yang telah ditentukan.Analisis multivariat menggunakan uji $\mathrm{F}$.

Hasil :Tidak ada hubungan antara umur, pendidikan, pekerjaan ibu dengan pemberian ASI eksklusif dengan hasil uji statistik diperoleh hasil p>0.05.Ada hubungan antara pengetahan tentang ASI eksklusif dengan pemberian ASI eksklusif dengan hasil uji statistik diperoleh hasil $\mathrm{p}<0.05$

Simpulan :Umur, pendidikan, pekerjaan dan pengetahuan tentang ASI eksklusif secara bersama - sama berpengaruh terhadap pemberian ASI eksklusif dengan hasil uji statistik diperoleh F hitung > F tabel $(4.318>2.429)$.
\end{abstract}

Kata Kunci : Determinan, ASI, Eksklusif

\section{ABTRACT}

Background: Breast milk is a single food that can meet the needs of babies for up to 6 months. Exclusive breastfeeding (ASI) in the first 6 months of a baby's life, which is balanced with the provision of optimal complementary food (MP) ASI, is a public health intervention that is very effective and efficient in supporting toddler growth. 
Objective: this study aimed to determine the determinants of exclusive breastfeeding in the RW 12 of Mojosongo Surakarta,including age, education, work and mother's knowledge of Exclusive Breastfeeding

Method: This study included the type of analytic research with a cross sectional time approach. The population in this study were all mothers who had babies in RW 12 Mojosongo,Jebres,Surakarta. In this study using purposive sampling, namely the technique of determining the sample based on certain conditions, namely mothers who have babies over 6 months a number of 161 respondents the data collection tool in this study was a questionnaire. In determining the level of significance of the relationship was done by comparing, the value of chi squared $(x 2)$ count with the value of the chi-square $(x)$ table according to the level of significance that has been determined. Multivariate analysis using the F test.

Results: There was no relationship between ages, education, the work of mothers, with exclusive breastfeeding with the results of statistical tests obtained p>0.05. There is a relationship between the tightening of exclusive breastfeeding and exclusive breastfeeding with the results of statistical tests obtained $p<0.05$

Conclusion: Age, education, occupation and knowledge of exclusive breastfeeding together have the same effect on exclusive breastfeeding with the results of statistical tests obtained $F$ count $>F$ table $(4.318>2.429)$.

Keywords: Determinants, ASI, Exclusive

\section{PENDAHULUAN}

\section{A. Latar Belakang Masalah}

Stunting atau masalah kurang gizi kronis saat ini merupakan ancaman bagi generasi yang akan datang dengan jumlah kasus saat ini mencapai 9 juta. Angka ini mencapai diatas batas toleransi WHO dimana stunting yang disebabkan karena kekurangan zat gizi pada usia dini dapat meningkatkan kematian bayi dan anak, kerja otak tidak maksimal dan menurunkan kemampuan kognitif ( BKKBN, 2017).

Salah satu upaya penanggulangan stunting adalah dengan pemberian ASI eksklusif, namun sayangnya saat ini penurunan jumlah ibu yang menyusui ASI esklusif tinggal $30 \%$ saja.( BKKBN,2017). Cakupan Pemberian ASI eksklusif pada bayi $0-6$ bulan berfluktuatif . Hasil Survey Demografi dan Kesehatan Indonesia (SDKI) 2007 menunjukkan cakupan ASI eksklusif bayi $0-6$ bulan sebesar $32 \%$ dan menunjukkan adanya kenaikan $42 \%$ di tahun 2012 ( Kemenkes RI, 2014).

ASI merupakan makanan tunggal yang dapat memenuhi kebutuhan bayi hingga 6 bulan. ASI eksklusif 6 bulan pertama kehidupan bayi yang diimbangi dengan pemberian MP ASI yang optimal merupakan intervensi kesehatan masyarakat yang sangat efektif dan efisien dalam mendukung pertumbuhan balita.Sebaliknya pemberian MP ASI yang terlalu dini juga berhubungan dengan stunting pada anak (Siswati, T 2018).

Selain sebagai unsur growth factor, ASI saja selama 6 bulan dapat mengurangi risiko terjadi penyakit gastrointestinal dibandingkan dengan pemberian ASI hanya 3 bulan. Gangguan gastrointestinal yang dialami anak akan 
menghambat penyerapan makanan, sehingga jika hal ini terjadi dalam waktu yang lama dan berulang maka akan mengakibatkan anak mengalami kekurangan asupan makanan dan berdampak pada status gizi . (Siswati, T 2018).

Perilaku ibu menyusui merupakan perilaku kesehatan multidimensional merupakan pengaruh dari beberapa faktor yaitu demografi, biologi, psikologi dan sosial, banyak penelitian yang meneliti hal ini. Faktor sosiodemografik yang memiliki hubungan bermakna adalah usia ibu dan status pekerjaan ibu (Kurniawan, B., 2013).

Ada beberapa faktor yang menyebabkan bayi tidak diberikan ASI secara benar untuk memenuhi kebutuhan gizinya faktor tersebut adalah faktor karakteristik ibu, faktor bayi, lingkungan, dukungan keluarga , pendidikan kesehatan, sosial ekonomi dan budaya ( Budiharjo, 2013). Lingkungan perkotaan yang biasanya relatif banyak ibu yang bekerja menyebabkan ibu tidak bisa menyusui secara baik dan teratur. Hal ini terjadi disebabkan situasi tempat bekerja belum menyediakan sarana prasarana pendukung ibu dalam pemberian ASI misalnya tidak ada ruangan untuk memerah ASI serta fasilitas untuk menyimpan ASI, belum adanya tempat penitipan bayi sehingga ibu bekerja dapat menyusui bayinya pada saat tertentu ( Sihombing S, 2017).

Penelitian Astuti I (2013) menyatakan bahwa ada hubungan antara pendidikan dan pekerjaan ibu terhadap pemberian ASI eklusif. Selain itu penelitian Erni Y (2014) juga ada hubungan yang signifikan antara pengetahuan ibu bayi tentang ASI eksklusif dengan pemberian ASI eksklusif.Tingkat pendidikan ibu dan pengetahuan ibu merupakan faktor yang penting untuk mendukung keberhasilan pemberian ASI eksklusif, karena semakin tinggi tingkat pendidikan seseorang maka akan semakin mudah menerima informasi sehingga semakin banyak pengetahuan yang dimiliki. Sebaliknya pendidikan yang kurang bisa menghambat sikap seseorang terhadap hal - hal baru yang dikenalkan kepada mereka (Fikawati, 2012).

Berdasarkan latar belakang yang telah ada maka rumusan masalah dalam penelitian ini adalah : Apakah Determinan Pemberian ASI Eksklusif di RW 12 Kalurahan Mojosongo Surakarta?

\section{METODE PENELITIAN}

Penelitian ini termasuk jenis penelitian analitik dengan pendekatan waktu cross sectional. Populasi dalam penelitian ini adalah seluruh ibu yang mempunyai bayi di RW 12 Kalurahan Mojosongo Kecamatan Jebres Surakarta.Pada penelitian ini menggunakan purposive sampling yaitu teknik penentuan sampel berdasarkan syarat tertentu yaitu ibu yang memiliki bayi di atas 6 bulan sejumlah 161 responden

Alat pengumpulan data pada penelitian ini yaitu kuesioner.untuk mengetahui tingkat signifikasi hubungan dapat dilakukan dengan membandingkan nilai chi kuadrat $\left(\mathrm{x}^{2}\right)$ hitung dengan nilai chi kuadrat $(\mathrm{x})$ tabel sesuai dengan tingkat signifikan yang telah ditentukan. Analisis multivariat menggunakan uji $\mathrm{F}$ untuk mengetahui hubungan secara linear antara variabel umur, pendidikan, 
pekerjaan dan pengetahuan tentang ASI eksklusif terhadap pemberian ASI eksklusif

\section{HASIL DAN PEMBAHASAN}

Setelah dilaksanakan penelitian diperoleh hasil :

Tabel 1 Distribusi Frekuensi Karakteristik Responden

\begin{tabular}{cccc}
\hline $\begin{array}{c}\text { Karakteristik } \\
\text { Responden }\end{array}$ & Kategori & Frekuensi & $\%$ \\
\hline Umur & <35 tahun & 117 & 72.7 \\
& $>35$ tahun & 44 & 27.3 \\
Pendidikan & SD, SMP, SMA & 137 & 85.1 \\
& PT & 24 & 14.9 \\
Pekerjaan & Bekerja & 62 & 38.5 \\
& Tidak Bekerja & 99 & 61.5 \\
Pengetahuan Tentang ASI & < Rata - Rata & 74 & 46 \\
Eksklusif & > Rata - rata & 87 & 54 \\
\hline
\end{tabular}

Berdasarkan tabel 1 mayoritas karakteristik responden berdasarkan umur adalah < 35 tahun sebesar $117(72,7 \%)$, berdasarkan tingkat pendidikan adalah SD, SMP dan SMA sebesar $137(85,1 \%)$, berdasarkan pekerjaan tidak bekerja sebesar 99 $(61.5 \%)$ dan berdasarkan pengetahuan tentang ASI eksklusif diatas rata - rata 87 ( $54 \%)$.

Tabel 2 Distribusi Frekuensi Responden dalam Pemberian ASI Eksklusif

\begin{tabular}{lcc}
\hline \multicolumn{1}{c}{ Kategori } & Frekuensi & Prosentase $(\%)$ \\
\hline ASI Eksklusif & 102 & 63 \\
Tidak ASI Eksklusif & 59 & 37 \\
Junlah & 161 & 100 \\
\hline
\end{tabular}

Berdasarkan Tabel 2 mayoritas ibu memberikan ASI eksklusif sebesar 102 ( 62\%).

Tabel 3 Hubungan Antara Umur dengan Pemberian ASI Eksklusif

\begin{tabular}{lllll}
\hline Umur & ASI Eksklusif & $\begin{array}{l}\text { Tidak ASI } \\
\text { Eksklusdif }\end{array}$ & $\begin{array}{l}\text { Pearson Chi } \\
\text { Square }\end{array}$ & $\begin{array}{l}\text { Asymp.Sig } \\
\text { (2-sided) }\end{array}$ \\
\hline <35 Tahun & 79 & 38 & $3.202 \mathrm{a}$ & .074 \\
>35 Tahun & 23 & 21 & &
\end{tabular}

Berdasarkan tabel diatas mayoritas ibu memberikan ASI eksklusif pada umur $<35$ tahun, Hasil uji statistik diperoleh hasil p> 0.05 maka dapat disimpulkan tidak ada hubungan antara umur dengan pemberian ASI eksklusif. 
Jurnal Kebidanan Indonesia. Vol 10 No 2. Juli $2019(92-101)$

Tabel 4 Hubungan Antara Pendidikan dengan Pemberian ASI Eksklusif

\begin{tabular}{lllll}
\hline Pendidikan & ASI Eksklusif & $\begin{array}{l}\text { Tidak ASI } \\
\text { Eksklusif }\end{array}$ & $\begin{array}{l}\text { Pearson Chi } \\
\text { Square }\end{array}$ & $\begin{array}{l}\text { Asymp.Sig } \\
\text { (2-sided) }\end{array}$ \\
\hline SD,SMP,SMA & 83 & 54 & $3.038 \mathrm{a}$ & .081 \\
PT & 19 & 5 & &
\end{tabular}

Mayoritas tingkat pendidikan ibu yang memberikan ASI eksklusif adalaah SD, SMP dan SMA. Hasil uji statistik diperoleh hasil p>0.05 maka dapat disimpulkan tidak ada hubungan antara tingkat pendidikan dengan pemberian ASI eksklusif.

Tabel 5 Hubungan Antara Pekerjaan dengan Pemberian ASI Eksklusif

\begin{tabular}{lllll}
\hline Pekerjaan & $\begin{array}{l}\text { ASI } \\
\text { Eksklusif }\end{array}$ & $\begin{array}{l}\text { Tidak ASI } \\
\text { Eksklusif }\end{array}$ & $\begin{array}{l}\text { Person } \\
\text { Square }\end{array}$ & $\begin{array}{l}\text { Chi } \\
\text { (2-sided) }\end{array}$ \\
\hline Bekerja & 42 & 20 & $.836 \mathrm{a}$ & .360 \\
Tidak Bekerja & 60 & 39 & &
\end{tabular}

Mayoritas status pekerjaan ibu yang memberikan ASI eksklusif adalah tidak bekerja. Hasil uji statistik diperoleh hasil $\mathrm{p}>0.05$ maka dapat disimpulkan tidak ada hubungan antara status pekerjaan dengan pemberian ASI eksklusif.

Semakin cukup umur seseorang maka akan semakin baik tingkat kematangan, kekuatan seseorang berfikir dan bekerja. Namun terkait pemberian ASI eksklusif ini banyak yang berada di usia kurang dari 35 tahun, hal ini terkait dengan usia reproduksi sehat seorang wanita yang tentunya akan berdampak pada jumlah bayi yang menjadi responden dalam penelitian ini.

Tabel 6 Hubungan Antara Pengetahuan tentang ASI Eksklusif dengan Pemberian

\begin{tabular}{|c|c|c|c|c|c|}
\hline $\begin{array}{l}\text { Pengetahuan } \\
\text { Eksklusif }\end{array}$ & ASI & $\begin{array}{l}\text { ASI } \\
\text { Eksklusif }\end{array}$ & $\begin{array}{l}\text { Tidak ASI } \\
\text { Eksklusif }\end{array}$ & $\begin{array}{l}\text { Person Chi } \\
\text { Square }\end{array}$ & $\begin{array}{l}\text { Asymp.Sig } \\
\text { (2-sided) }\end{array}$ \\
\hline$<$ Rata - rata $(83)$ & & 36 & 38 & $12.755 \mathrm{a}$ & .000 \\
\hline$>$ Rata - rata (83) & & 66 & 21 & & \\
\hline
\end{tabular}

Berdasarkan tingkat pengetahuan ibu tentang ASI eksklusif mayoritas $>$ rata - rata (83). Hasil uji statistik diperoleh hasil $\mathrm{p}<0.05$ maka dapat disimpulkan ada hubungan antara pengetahuan ibu tentang ASI eksklusif dengan pemberian ASI eksklusif.

Tabel 7 Hasil Uji F

\begin{tabular}{lccccc}
\hline \multicolumn{1}{c}{ Model } & $\begin{array}{c}\text { Sum of } \\
\text { Squares }\end{array}$ & df & $\begin{array}{c}\text { Mean } \\
\text { Squares }\end{array}$ & F & Sig. \\
\hline 1 Regression & 3.726 & 4 & .931 & 4.318 & $.002 \mathrm{a}$ \\
Residual & 33.653 & 156 & .216 & & \\
Total & 37.379 & 160 & & & \\
& & & & & \\
\hline
\end{tabular}


Berdasarkan hasil diatas diperoleh $\mathrm{F}$ hitung > F table $(4.318>2.429)$, maka dapat disimpulkan bahwa umur, pendidikan, pekerjaan dan pengetahuan tentang ASI eksklusifsecara bersama - sama berpengaruh terhadap pemberian ASI eksklusif.

Umur yaitu usia individu yang terhitung mulai saat dilahirkan sampai saat berulang tahun. Semakin meningkat umur seseorang maka semakin tinggi kematangan dan kekuatan seseorang sehingga cara berfikir dan bekerja seseorang semakin optimal. Kepercayaan masyarakat terhadap seseorang yang lebih dewasa akan meningkat. Hal ini akan sebagai dari pengalaman dan kematangan jiwa.

Mayoritas umur ibu yang memberikan ASI ekklusif adalah $<35$ tahun. Berdasarkan hasil uji statistik diperoleh hasil $\mathrm{p}>0.05$ maka dapat disimpulkan bahwa tidak ada hubungan antara umur ibu dengan pemberian ASI eksklusif. Hal ini didukung hasil penelitian Untari (2017) dan Astuti (2013) bahwa tidak ada hubungan antara umur ibu dengan pemberian ASI Eksklusif. Penelitian Oselaguri (2012) juga mendukung hasil penelitian ini bahwa tidak ada hubungan faktor umur dengan pemberian ASI eksklusif, hal ini disebabkan ibu yang memiliki umur lebih dari 30 tahun memiliki anak dengan jumlah yang lebih banyak sehingga pemberian ASI eksklusif tidak berhasil selain itu frekuensi menyusui juga semakin berkurang. Selain ini ketidakberhasilan pemberian ASI eksklusif disebabkan oleh pengalaman ibu sebelumnya yang berpendapat bahwa anak yang tidak diberikan ASI eksklusif tumbuh kembangnya sudah sesuai dan sehat sehingga ibu tidak memberikan ASI eksklusif kepada anak berikutnya, padahal di sisi lain ASI memiliki manfaat makanan "terlengkap" untuk bayi, terdiri dari proporsi yang seimbang dan cukup mengandung zat gizi yang diperlukan untuk 6 bulan pertama., mengandung antibodi (terutama kolostrum) yang melindungi terhadap penyakit diare dan gangguan pernapasan. Serta menunjang perkembangan motorik sehingga bayi yang diberi ASI ekslusif akan lebih cepat bisa jalan.

Berdasarkan hasil penelitian Kurniawan B (2013) diperoleh hasil usia ibu memiliki hubungan yang bermakna dengan keberhasilan ibu dalam memberikan ASI eksklusif. Bertambahnya usia ibu ternyata meningkatkan kegagalan dalam pemberian ASI eksklusif.

Umur seseorang yang semakin beertambah maka akan semakin baik tingkat kematangan, kekuatan seseorang berfikir dan bekerja.Namun terkait pemberian ASI eksklusif ini banyak yang berada di usia kurang dari 35 tahun, hal ini terkait dengan usia reproduksi sehat seorang wanita yang tentunya akan berdampak pada jumlah bayi yang menjadi responden dalam penelitian ini.

Pendidikan merupakan salah satu kebutuhan pokok manusia dalam upaya pengembangan diri. Tingkat pendidikan seseorang yang semakin tinggi akan berdampak pada kemudahan menerima dan mengembangkan pengetahuan serta teknologi yang akan meningkatkan kesejahteraan keluarga. Notoatmodjo (2010) menyebutkan bahwa pendidikan merupakan proses belajar yang meliputi tahap pertumbuhan dan perkembangan menuju kedewasaan dan kematangan pada diri individu, kelompok atau masyarakat. Pendidikan ibu merupakan salah satu faktor penting dalam pemberian ASI eksklusif. 
Hasil penelitian diperoleh hasil $\mathrm{p}>0.05$ maka dapat disimpulkan bahwa tidak ada hubungan antara pendidikan ibu dengan pemberian ASI eksklusif. Pada penelitian ini proporsi responden yg berpendidikan SD,SMP,SMA lebih banyak atau tidak sebanding dengan proporsi responden yang berpendidikan perguruan tinggi. Hal ini sesuai dengan penelitian Untari J (2017) yang menyataan bahwa tidak ada hubungan yang signifikan antara pendidikan ibu dengan pemberian ASI eksklusif. Pendidikan ibu yang tinggi tentunya akan memberikan peluang untuk ibu memperoleh pekerjaan yang tentunya hal ini memiliki tantangan tersendiri terkait pemberian ASI eksklusif.

Penelitian ini bertolak belakang dengan hasil penelitian Astuti (2013) yang menyatakan ada hubungan antara pendidikan ibu dengan pemberian ASI eksklusif.

Salah satu keberhasilan dari pemberian ASI eksklusif adalah status pekerjaan ibu. Conita (2014) menjelaskan bahwa pekerjaan bagi seorang ibu berhubungan sangat erat dengan kecukupan waktu luang bagi bayi dari seorang ibu. Ibu yang menghabiskan waktu di luar rumah maka akan mengakibatkan berkurangnya waktu kebersamaan antara ibu dan anak.

Hasil penelitian ini menunjukkan hasil bahwa mayoritas ibu yang memberikan ASI eksklusif adalah ibu yang tidak bekerja karena ibu lebih banyak memberikan waktu luang bersama bayinya. Kondisi ibu bekerja di Indonesia terkait dengan perilaku pemberian ASI eksklusif ini tidak mendapat dukungan dengan adanya Undang-Undang Nomor 13 Tahun 2003 tentang Ketenagakerjaan (UU Ketenagakerjaan)yaitu berdasarkan Pasal 82 ayat (1) dan Pasal 84 bahwa pekerja/buruh perempuan (maksudnya, "karyawan wanita" atau karyawati), berhak memperoleh istirahat atau cuti hamil selama 1,5 bulan (dalam arti, satu bulan dan lima belas hari) sebelum saatnya melahirkan anak, dan cuti melahirkan selama 1,5 bulan (satu bulan dan 15 hari) sesudah melahirkan, menurut perhitungan dokter kandungan atau bidan.

Di sisi lain pemerintah juga mengeluarkan Peraturan Pemerintah Republik Indonesia tentang Pemberian Air Susu Ibu Eksklusif dalam Bab III Pasal 6 yaitu bahwa setiap ibu yang melahirkan harus memberikan ASI eksklusif kepada bayi yang dilahirkannya. Hal ini tentunya menjadi tantangan bagi ibu yang bekerja untuk tetap memberikan ASI secara eksklusif dengan memanfaatkan informasi kesehatan yang ada dengan memberikan ASI perah pada saat si ibu sudah bekerja yang tentunya seharusnya didukung dengan fasilitas dari instansi tempat bekerja untuk menyediakan bilik ASI dan fasilitas kulkas / freezer untuk mewujudkan program pemerintah tersebut.

Hasil uji statistik diperoleh hasil $\mathrm{p}>0.05$ maka dapat disimpulkan bahwa tidak ada hubungan antara pekerjaan ibu dengan pemberian ASI eksklusif. Penelitian ini berbeda dengan hasil penelitian Kurniawan B (2013) yang menyebutkan bahwa status pekerjaan ibu memiliki hubungan dengan keberhasilan pemberian ASI eksklusif, hal ini disebabkan ibu bekerja mempunyai masalah dalam pemberian ASI eksklusif kepada bayinya yaitu tidak tersedianya alokasi waktu yang cukup, kurangnya waktu kebersamaan bersama bayinya, beban kerja yang berlebihan serta stress yang bisa menyebabkan kecukupan ASI berkurang. 
Pengetahuan merupakan hasil dari tahu, dan ini terjadi setelah orang melakukan pengindraan terhadap suatu objek tertentu. Pengindraan terjadi melalui pancaindra manusia, yakni indra penglihatan, pendengaran, penciuman, rasa dan raba. Sebagian besar pengetahuan manusia diperoleh melalui mata dan telinga. Pengetahuan atau kognitif merupakan domain yang sangat penting dalam membentuk tindakan seseorang (Notoadmojo, S, 2007).

Dari hasil penelitian diperoleh hasil mayoritas ibu yang memberikan ASI eksklusif memiliki pengetahuan yang baik yaitu diatas rata - rata. Hasil uji statistik memiliki $\mathrm{p}<0.05$ sehingga dapat disimpulkan ada hubungan antara pengetahuan ibu dengan pemberian ASI eksklusif. Hal ini sesuai dengan hasil penelitian Astuti (2013) dan Yuniastuti E (2014) yang menyatakan bahwa ada hubungan antara pengetahuan ibu dengan pemberian ASI ekskusif di Kalurahan Palebon Kecamatan Pedurungan Kota Semarang.Pengetahuan adalah pijakan utama manusia untuk melakukan suatu kegiatan serta merupakan faktor pendorong berhasilnya pemberian ASI eksklusif.

Penelitian yang berbeda hasilnya dilakukan oleh Sugiarti, E (2011) yang menyatakan bahwa tidak ada hubungan antara pengetahuan ibu dengan pemberian ASI eksklusif. Hasil penelitian ini diperoleh hasil bahwa sebagian besar responden memiliki pengetahuan baik tetapi tidak mempengaruhi pemberian ASI eksklusif adapun salah satu penyebabnya adalah tingkat pengetahuan yang dimiliki responden berada pada tingkat tahu yang merupakan tingkatan paling awal dalam taksonomi Bloom sehingga tidak mendorong untuk merubah perilaku seseorang. (Azwar S, 2011)

Berdasarkan hasil penelitian diperoleh $\mathrm{F}$ hitung > F tabel $(4.318>2.429)$., maka dapat disimpulkan bahwa umur, pendidikan, pekerjaan dan pengetahuan tentang ASI eksklusif secara bersama - sama berpengaruh terhadap pemberian ASI eksklusif. Penelitian ini bertolak belakang dengan penelitian Sartono A, (2012) bahwa tidak ada hubungan yang bermakna antara pendidikan, pengetahuan dan dukungan suami secara bersama dalam pemberian ASI eksklusif.

Ada beberapa faktor yang menyebabkan bayi tidak diberikan ASI secara benar untuk memenuhi kebutuhan gizinya $\mathrm{F}$ hitung $>\mathrm{F}$ tabel $(4.318>2.429)$. tersebut adalah $\mathrm{F}$ hitung $>\mathrm{F}$ tabel $(4.318>2.429)$. $\mathrm{r}$ karakteristik ibu, $\mathrm{F}$ hitung $>\mathrm{F}$ tabel (4.318 >2.429). bayi, lingkungan, dukungan keluarga, pendidikan kesehatan, sosial ekonomi dan budaya( Budiharjo, 2013). Lingkungan perkotaan yang biasanya relatif banyak ibu yang bekerja menyebabkan ibu tidak bisa menyusui secara baik dan teratur. Hal ini terjadi disebabkan situasi tempat bekerja belum menyediakan sarana prasarana pendukung ibu dalam pemberian ASI misalnya tidak ada ruangan untuk memerah ASI serta fasilitas untuk menyimpan ASI, belum adanya tempat penitipan bayi sehingga ibu bekerja dapat menyusui bayinya pada saat tertentu ( Sihombing S, 2017).

\section{SIMPULAN DAN SARAN}

\section{Simpulan}

Tidak ada hubungan antara umur, pendidikan, pekerjaan ibu dengan pemberian ASI eksklusif dengan hasil uji statistik diperoleh hasil $\mathrm{p}>0.05$.Ada 
hubungan antara pengetahuan tentang ASI eksklusif dengan pemberian ASI eksklusif dengan hasil uji statistik diperoleh hasil $\mathrm{p}<0.05$. Umur, pendidikan, pekerjaan dan pengetahuan tentang ASI eksklusif secara bersama - sama berpengaruh terhadap pemberian ASI eksklusif dengan hasil uji statistik diperoleh $\mathrm{F}$ hitung $>\mathrm{F}$ tabel $(4.318>2.429)$.

\section{Saran}

Bagi responden supaya lebih aktif lagi dalam kegiatan posyandu balita sehingga bisa menambah informasi kesehatan terkait kebutuhan kesehatan bagi bayinya sehingga pengetahuan bertambah dan akan merubah tingkatan pengetahuannya yang memperkuat perubahan perilaku kesehatan. Bagi peneliti selanjutnya adanya pengembangan variabel yang lain untuk bisa diteliti yaitu dari jenis informasi kesehatan yang diperoleh serta dukungan suami dalam pemberian ASI eksklusif

\section{DAFTAR PUSTAKA}

Astuti, I., 2013. Determinan pemberian ASI eksklusif pada ibu menyusui.Jurnal Health Quality, 4(1), pp.176.https://www.poltekkesjakarta1.ac.id/file/dokumen/41Jurnal_ISRONI.pd f.

Azwar, S.2011. Tes Prestasi Fungsi dan Pengembangan Pengukuran Prestasi Belajar.Yogyakarta. Pustaka Pelajar Offset

BKKBN, 2017. Peran BKKBN di Balik Gerakan Penanggulangan Stunting. Jurnal Keluarga.Edisi Kesatu 2018. www.bkkbn.go.id

Budiharjo, 2013.Panduan Ibu Cerdas ( ASI dan Tumbuh Kembang Bayi). Yogyakarta: Medis Presindo

Conita, D.A., Perbedaan Pertumbuhan Bayi Usia 3-6 Bulan yang Diberi Asi Eksklusif dan yang Tidak Diberi Asi Eksklusif di Puskesmas Gang Sehat Kecamatan Pontianak Selatan. Jurnal Mahasiswa PSPD FK Universitas Tanjungpura, 1(1).

Fikawati, S dan Syafig, A.2012.Kajian Implementasi dan Kebijakan Air Susu Ibu Eksklusif dan Inisiasi Menyusu Dini Di Indonesia.Jakarta : EGC

Fitri Yunita. 2008. Hubungan Pengetahuan Ibu Tentang ASI Eksklusif Dengan Status Gizi Bayi Umur 0-6 Bulan Di Wilayah Kerja Puskesmas Tambak 1 Kabupaten Banyumas Tahun 2008. STIKES Muhammadiyah Gombong.

Kemenkes RI. 2014. Situasi dan Analisis ASI Eksklusif. Jakarta : Pusat Data dan Informasi

Kurniawan, B., 2013. Determinan keberhasilan pemberian air susu ibu eksklusif. Jurnal Kedokteran Brawijaya, 27(4), pp.236-240.

Mabud, N.H., Mandang, J. and Mamuaya, T., 2014.Hubungan pengetahuan, pendidikan, paritas dengan pemberian ASI eksklusif di Puskesmas Bahu Kecamatan Malalayang Kota Manado.JIDAN (Jurnal Ilmiah Bidan), 2(2), pp.51-56. 
Notoatmodjo, S. 2007. Promosi Kesehatan dan Ilmu Perilaku. Jakarta. Rineka Cipta

Notoatmodjo, S.2011. Metodologi Penelitin Kesehatan. Jakarta. Rineka Cipta

Sartono, A. and Utaminingrum, H., 2012. Hubungan Pengetahuan Ibu, Pendidikan Ibu dan Dukungan Suami dengan Praktek Pemberian Asi Eksklusif di Kelurahan Muktiharjo Kidul Kecamatan Telogosari Kota Semarang. Jurnal Gizi, 1(1).

Sihombing, S. 2017. Hubungan Pekerjaan dan Pendidikan Ibu dengan Pemberian ASI Eksklusif di Wilayah Kerja Puskesmas Hinai Kiri Tahun 2017.Jurnal bidan "Midwife Journal” Volume 5 No 01, Jan 2018.

Siswati, T 2018.Stunting.Yogyakarta. Husada Mandiri

Sugiarti, E., Zulaekah, S. and Puspowati, S.D., 2011. FAKTOR-FAKTOR YANG BERHUBUNGAN DENGAN PEMBERIAN ASI EKSKLUSIF DI KECAMATAN KARANGMALANG KABUPATEN SRAGEN

Untari, J., 2017, April. Hubungan antara karakteristik ibu dengan pemberian ASI eksklusif di Wilayah Kerja Puskesmas Minggir Kabupaten Sleman.In Jurnal Formil (Forum Ilmiah) KesMas Respati (Vol. 2, No. 1).

Wardani L,2011. Hubungan Pemberian ASI Eksklusif dengan Tumbuh Kembang Bayi di Puskesmas Pecalungan Kecamatan Pecalungan Kabupaten Batang

Pengetahuan, Sikap dan Perilaku Manusi. Yogyakarta. Nuha Medika

Yuniastuti, Erni, and Ani Nur Fauziah. "HUBUNGAN PENGETAHUAN IBU BAYI TENTANG ASI EKSKLUSIF DENGAN PEMBERIAN ASI EKSKLUSIF DI PUSKESMAS GIRIMARTO WONOGIRI TAHUN 2013." Jurnal Kebidanan Indonesia: Journal of Indonesia Midwifery 5, no. 2 (2014). 